
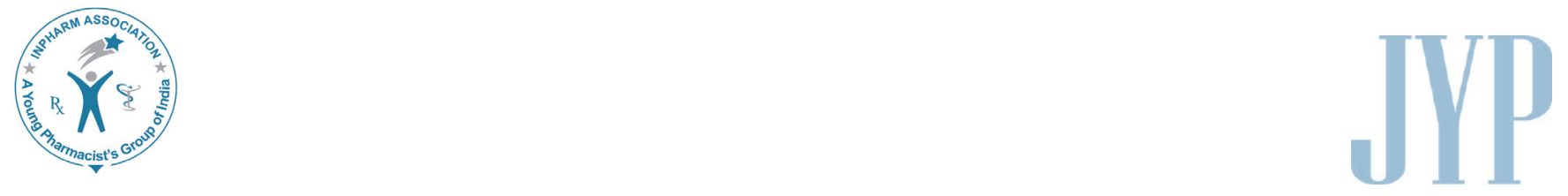

\title{
In silico siRNA design for SNPs in HER family receptors: A Potential cure for Cancer
}

\author{
Ravindra Babu Potti ${ }^{*}$ Jayasree Ganugapati, Aishwarya Mandava, Pranusha \\ Reddy Mallepalli and Dharani Matha
}

\author{
Department of Biotechnology, Sreenidhi Institute of Science and Technology, Yamnampet, Ghatkesar, \\ Hyderabad-501301, India.
}

\begin{abstract}
Background: Silencing of a specific mRNA using double stranded RNA oligo nucleotides represents novel technologies for suppressing a specific gene product. Small interfering RNA (siRNA) are 21 nucleotides long, double stranded RNA fragments that interferes with the expression of specific genes with complementary nucleotide sequences. siRNA functions by breaking down mRNA after transcription, resulting in no translation. HER/ErbB is a family of receptors that has HER1, HER2, HER3 and HER4 as its members. Certain mutations in these receptors leads to its over expression. Amplification or over expression of these receptors has shown to play an important role in the development and progression of certain aggressive types of breast cancer, colon and gastric cancers. The SNPs in Her1 receptor were observed at first position, in HER2 at eighth position, in HER3 at first position and in HER4 at third position. Methods: siDirect is a software that enables In silico siRNA design. The parameters like GC Content and Thermodymics were considered for designing the siRNA sequences against selected mRNA sequences of HER family. The phylogram was also analyzed by constructing the mulpitle sequence alignment using Clustalw to assess the similarity between the siRNA target sequences. Results: The SNPs identified in HER1, HER2, HER3, HER4 family of receptors are missense mutations, any change in nucleotide level are altering the protein sequence structure and function. The mRNA sequences with SNPs positions were submitted to the siRNA Direct 2.0. Set of possible siRNA sequences with 21 nucleotides and the positions where they are targeted. The best possible siRNA sequences were validated using online tools. Conclusion: The siRNA sequences that were identified are considered to be the best suitable for controlling the overexpression of the target mRNA sequences thereby minimizing the development of cancer.
\end{abstract}

Key words: Breast cancer, Gene silencing, HER1, HER2, HER3, HER4, siRNA.

\section{INTRODUCTION}

Gene silencing is the ability of a cell to prevent the expression of a certain gene. RNA interference (RNAi)

\begin{tabular}{|c|c|}
\hline \multicolumn{2}{|c|}{ Access this article online } \\
\hline Journal Sponsor & \multirow[b]{2}{*}{$\begin{array}{l}\text { Website: } \\
\text { www.jyoungpharm.org }\end{array}$} \\
\hline \multirow{2}{*}{ www.phcog net } & \\
\hline & $\begin{array}{l}\text { DOI: } \\
\text { 10.5530/jyp.2015.4s.4 }\end{array}$ \\
\hline
\end{tabular}

is a post-transcriptional gene silencing process during which the expression of endogenous mRNA is blocked by introducing a double-strand RNA (dsRNA). ${ }^{1}$ The mechanism of RNAi can be illustrated as, firstly, the Dicer enzyme binds to dsRNA cleaving it into $21 \sim 23$ nucleotide fragments called short interference RNA (siRNA). The siRNA then binds to the RNA-induced silencing complex (RISC) and gets separated into the guide strand (antisense to the target mRNA) staying in the RISC, and the passenger strand (sense to the target mRNA) that is released and

*Address for correspondence:

Dr. Ravindra Babu Potti, Department of Biotechnology, Sreenidhi Institute of Science and Technology, Yamnampet, Ghatkesar road, Hyderabad-50130,India.E-mail: ravindrap@sreenidhi.edu.in 
degraded. ${ }^{2}$ The siRNA-RISC complex then recognizes the target mRNA with guide strand pairing up with the complementary mRNA sequence. ${ }^{3}$ The target mRNA is cut by Ago protein, which ultimately results in an efficient inhibition of gene expression. ${ }^{4}$

\section{HER FAMILY OF RECEPTORS}

The HER family consists of tyrosine kinase receptors that are activated following receptor dimerization and ligand binding. The HER family consists of four structurally related receptors: HER1 (EGFR), HER2, HER3, and HER $4 .{ }^{5}$ They regulate multiple processes out of which cell cycle progression, differentiation and apoptosis are significant. Dysregulation of HER-mediated signaling pathways results in growth and spread of cancer cells. ${ }^{5}$ HER family receptors are activated upon ligand-induced dimerization, or receptor pairing. ${ }^{6}$ The dimer formation results in activation of its kinase domain, which leads to the activation of the MAPK proliferation pathway and/ or the PI3K. ${ }^{7,8}$ Inappropriate signaling usually leads to uncontrolled cell proliferation, reduced apoptosis and angiogenesis. ${ }^{9-11}$

\section{HER1}

HER1/EGFR has an extracellular domain that can bind multiple ligands, such as $\mathrm{EGF}^{12}$ and an intracellular kinase domain. ${ }^{13}$ Inappropriate HER1/EGFR signaling is enhanced in cancer cells due to amplification of its gene, ${ }^{12}$ over expression of receptors and ligands. ${ }^{14-16}$ Dysfunctional HER1/EGFR receptors initiate downstream signaling pathways such as the PI3K, MAPK kinase, STAT3, FAK signaling pathway. ${ }^{14}$

\section{HER2}

Amplification of HER2 oncogene plays significant role in the development of certain aggressive types of breast cancer ${ }^{17}$ and is also known to occur in ovarian and aggressive forms of uterine cancer. Although all four HER family receptors are capable of dimerizing with each other, HER2 is the preferred dimerization partner. ${ }^{18}$ HER2-containing dimers have increased signaling potency relative to dimers that do not contain HER2. ${ }^{19}$ HER2, when dimerized with HER3, is an activator of the PI3K signaling pathway ${ }^{19}$ which leads to a more invasive cellular phenotype. The dimer formed by HER 2 and HER1 is also of importance, particularly in ovarian cancer ${ }^{20}$ and is the most commonly formed dimer in response to stimulation with epidermal growth factor (EGF). Its activation leads to initiation of the mitogen-activated protein kinase (MAPK) pathway.

\section{HER3}

During human development, HER3 gene(ERBB3) is expressed in skin, bone, muscle, nervous system, heart, lungs, and intestinal epithelium. ${ }^{21}$ ErbB3 has been shown to bind the ligands heregulin and Neuregulin-1,2. HER3 lacks intrinsic tyrosine kinase activity. ${ }^{22}$ HER2 requires HER3 in order to transform normal cells into cancer cells. ${ }^{23}$ HER3 is involved in HER2-mediated tumorigenesis through dimerization with HER2 and enables HER2 to activate the PI3K signaling pathway. ${ }^{23}$ HER2 increases signaling potency, making the HER2:HER3 heterodimer a particularly effective initiator of PI3K. ${ }^{24-27}$ When HER2 is targeted using a tyrosine kinase inhibitor, tumor cells can compensate by upregulating HER3 activation. HER2:HER3 heterodimers thus remain active, preserving downstream signaling pathways even in the presence of tyrosine kinase inhibition. ${ }^{22}$

\section{HER4}

HER4, like HER1/EGFR, contains both a ligandbinding domain and a tyrosine kinase domain ${ }^{28}$ HER4 ligands include heregulin, the neuregulins, betacellulin, and epiregulin..$^{29,30}$ One preclinical study (Campiglio et al, 1999) suggests that HER3/HER4 heterodimers may be responsible for prolonged activation of mitogenassociated protein kinase (MAPK), which leads to cellular proliferation. ${ }^{30}$

\section{MATERIALS AND METHODS}

\section{Retrieval of sequence and identification of SNPS}

The SNPs in HER family receptors(one SNP for each receptor) are identified from NCBI-dbSNP. ${ }^{31}$ Recent literature shows that these SNPs have a crucial role in cancer. The accession numbers, the Position, type of mutation, allele change, Amino acid change of these SNPs are obtained from dbSNP and are indicated in Table 1. The SNPs are selected based on these parameters. Since dbSNP does not have mRNA sequence with SNP change, the ten reference mRNA sequences of HER family are retrieved from NCBI database and the allele changes were done manually, counting the position where the change has occurred.

\section{Identification of the target and designing potential siRNA molecule}

The mRNA sequences of HER family after allele changes are done are submitted to siDirect2. It is an 
Table 1: Details of SNPs in HER family of proteins

\begin{tabular}{|c|c|c|c|c|c|c|}
\hline Receptor & $\begin{array}{c}\text { Accession } \\
\text { number of SNP }\end{array}$ & Mutation & $\begin{array}{l}\text { Reference } \\
\text { sequence of } \\
\text { mRNA }\end{array}$ & $\begin{array}{l}\text { Position of SNP } \\
\text { on mRNA }\end{array}$ & Allele change & $\begin{array}{l}\text { Amino acid } \\
\text { change }\end{array}$ \\
\hline HER1 & rs28929495 & missense & NM_005228.3 & 2401 & $\mathrm{GGC} \Rightarrow \mathrm{AGC}$ & Gly to ser \\
\hline \multirow{5}{*}{ HER2 } & \multirow{5}{*}{ rs1058808 } & \multirow{5}{*}{ missense } & XM_006721765.1 & 3751 & \multirow{5}{*}{$\mathrm{CCC} \Rightarrow \mathrm{GCC}$} & \multirow{5}{*}{ Proto Ala } \\
\hline & & & XM_005257140.1 & 3437 & & \\
\hline & & & NM_004448.3 & 3769 & & \\
\hline & & & NM_001289936.1 & 4045 & & \\
\hline & & & NM_001005862.2 & 3994 & & \\
\hline HER3 & rs151311358 & missense & NM_001982.3 & 3421 & $\mathrm{AGT} \Rightarrow \mathrm{CGT}$ & Serto Arg \\
\hline \multirow{3}{*}{ HER4 } & \multirow{3}{*}{ rs142249882 } & \multirow{3}{*}{ missense } & XM_005246376.1 & 2693 & \multirow{3}{*}{$\mathrm{CCC} \Rightarrow \mathrm{TCC}$} & \multirow{3}{*}{ ProtoSer } \\
\hline & & & XM_005246375.1 & 2768 & & \\
\hline & & & NM_001042599.1 & 2196 & & \\
\hline
\end{tabular}

\begin{tabular}{|c|c|c|}
\hline Ui-Tei Rules & Amarzguioui Rules & Reynolds Rules \\
\hline $\begin{array}{c}\mathrm{A} / \mathrm{U} \text { at the } 5 \text { ' terminus of the sense } \\
\text { strand }\end{array}$ & $\begin{array}{l}\text { Duplex End A/U differential }>0 \text {. } \\
\text { Strong binding of } 5 \text { 'sense strand }\end{array}$ & $\begin{array}{l}\text { Each rule is assigned a score which is } \\
\text { summed up to a total duplex score to } \\
\text { improve the efficacy of siRNA. }\end{array}$ \\
\hline $\begin{array}{l}\mathrm{G} / \mathrm{C} \text { at the } 5 \text { ' terminus of the } \\
\text { antisense Strand }\end{array}$ & $\begin{array}{l}\text { No } U \text { atposition 1. Presence of } A \text { at } \\
\text { position } 6 \text {. }\end{array}$ & - \\
\hline $\begin{array}{l}\text { At least } 4 \mathrm{~A} / \mathrm{U} \text { residues in the } 5 \\
\text { terminal } 7 \text { bp of sense strand }\end{array}$ & $\begin{array}{l}\text { Weak binding of 3'sense strand. No } \\
\text { Gatposition } 19 .\end{array}$ & - \\
\hline No GC stretch longer than $9 \mathrm{nt}$ & - & - \\
\hline
\end{tabular}

siRNA designing software available online. ${ }^{32}$ The siRNA molecules are designed using combined approach of Ui-Tei, Amarzguioui and Reynolds rules. ${ }^{33}$ The other parameter that was applied is melting temperature (Tm) below $21.5^{\circ} \mathrm{C}$ for siRNA duplex. The validation of the predicted siRNA molecules was performed using an online tool called siRNA at whitehead. This gives a list of siRNA sequences for each receptor and the best sequence is selected considering the melting temeperatures and GC content.

\section{The following steps were followed by siDirect 2.0 for designing siRNA}

\section{Step 1: Selection of Functional siRNAs}

Functional siRNA sequences were selected based on the algorithm used in siDirect. Three sequence parameters were considered for the selection of siRNA namely A/U at the $5^{\prime}$ terminus of the guide strand; $\mathrm{G} / \mathrm{C}$ at the $5^{\prime}$ terminus of the passenger strand; at least $4 \mathrm{~A} / \mathrm{U}$ residues in the $5^{\prime}$ terminal $7 \mathrm{bp}$ of the guide strand and absence of $\mathrm{G} / \mathrm{C}$ stretch longer than $9 \mathrm{bp} .{ }^{34}$ The rules followed for siRNA selection are given in Table 2 .

\section{Step 2: Reduction of off-target effects}

The thermodynamic stability or Tm is a key parameter to assess the off target effect of the seed target duplex. Tm was calculated using nearest neighbor model. In the present study the siRNAs having $\mathrm{Tm}$ below $21.5^{\circ} \mathrm{C}$ for both guide and passenger strands are selected in this study. ${ }^{35}$

Step 3: Elimination of near-perfect matched genes

siDirect 2.0 was used to perform off-target search for sequence of 19-mer at positions 2-20 of both strands of the siRNA duplex, since these 19 nucleotides are predicted to be involved in the recognition of target mRNA. siRNAs that have near-perfect matches with other non-targeted transcripts were eliminated from the study. siRNA sequences that have at least two mismatches to any other non-targeted transcripts were selected. ${ }^{36}$ The flowchart for the above said protocol is given in the Figure $1{ }^{32}$

\section{Similarity search and target alignment}

Blast search ${ }^{37}$ was performed for the siRNA sequences designed by siDirect2. This was done to identify any off target sequence similarity with non targeted sequences. This was done by applying expected thresholds value 10 and BLOSUM 62 matrix as parameter.

\section{GC calculation}

GC calculator tool was used to calculate the GC content for selected siRNA molecule.

Thermodynamics of predicted siRNA and target gene

To study the thermodynamics of interaction between predicted siRNA and target gene, RNA cofold program ${ }^{38}$ was used. It calculates the hybridization energy and basepairing form of two RNA sequences. 


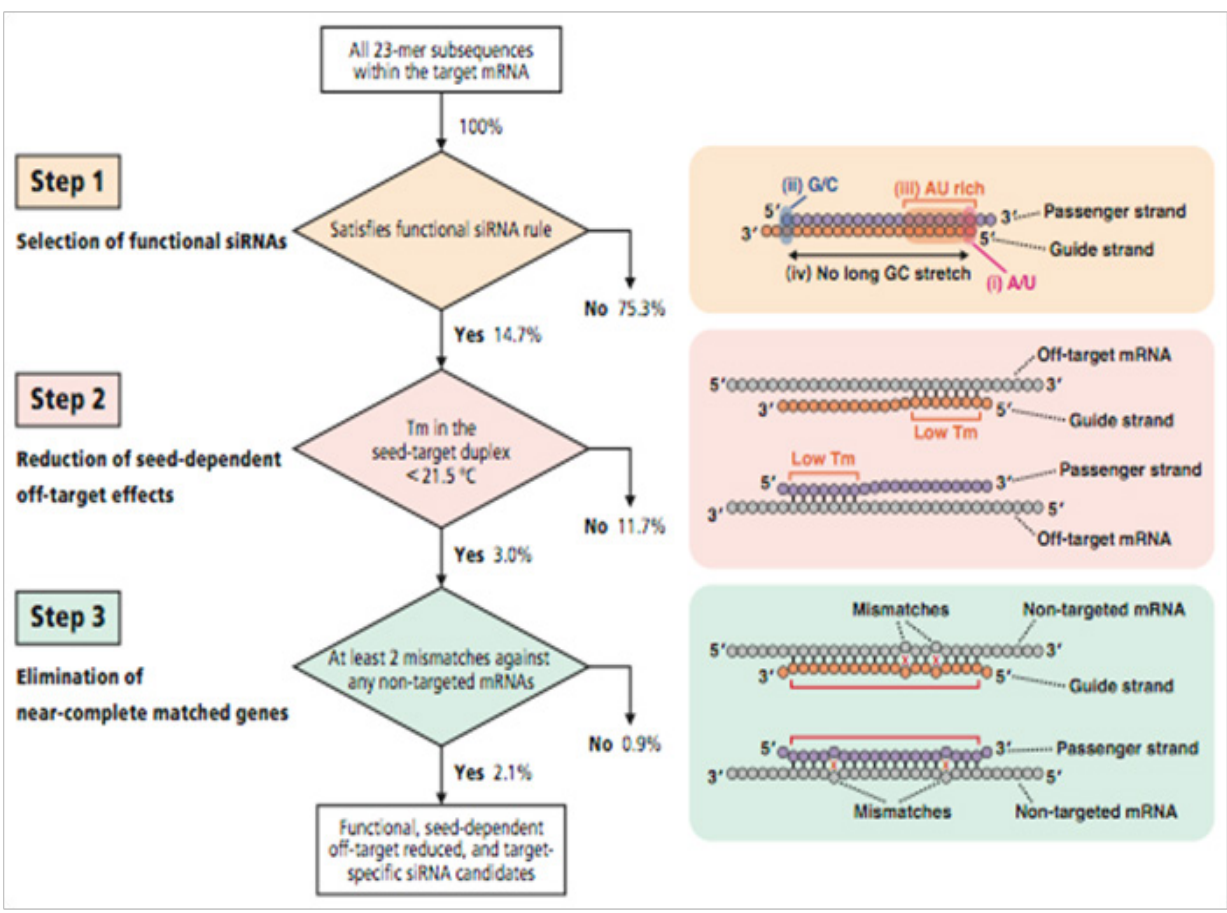

Figure 1: Protocol for SiRNA design, Source: SiDirect 2.0

\begin{tabular}{|c|c|c|c|c|c|c|c|c|}
\hline Receptor & $\begin{array}{c}\text { Accession } \\
\text { No.Reference } \\
\text { mRNA sequence }\end{array}$ & $\begin{array}{l}\text { Position } \\
\text { on mRNA } \\
\text { (target) }\end{array}$ & $\begin{array}{l}\text { Guide sequence } \\
\text { of SiRNA 5'-> 3' }\end{array}$ & $\begin{array}{l}\text { Passenger sequence } \\
\text { of SiRNA } 3^{\prime}->5\end{array}$ & $\begin{array}{l}\text { Tm } \\
\text { Guide of } \\
\text { SiRNA }\end{array}$ & $\begin{array}{c}\text { Tm } \\
\text { Passenger } \\
\text { of SiRNA }\end{array}$ & $\begin{array}{c}\text { GC } \\
\text { content } \%\end{array}$ & $\begin{array}{l}\text { Free energy } \\
\text { of binding } \\
\mathrm{Kcal} / \mathrm{mol}\end{array}$ \\
\hline Her1 & NM_005228.3 & $467-489$ & $\begin{array}{l}\text { UCUUUAA } \\
\text { GAAGGAA } \\
\text { AGAUCAU }\end{array}$ & $\begin{array}{l}\text { GAUCUUU } \\
\text { CCUUCUU } \\
\text { AAAGACC }\end{array}$ & 1.3 & 14.8 & 32 & -29.60 \\
\hline \multirow{5}{*}{ Her2 } & XM_006721765.1 & $3118-3140$ & $\begin{array}{l}\text { ACAUUCA } \\
\text { GAGUCAA } \\
\text { UCAUCCA }\end{array}$ & $\begin{array}{l}\text { GAUGAUU } \\
\text { GACUCUG } \\
\text { AAUGUCG }\end{array}$ & 18.1 & 13.6 & 37 & -34.40 \\
\hline & XM_005257140.1 & $2804-2826$ & $\begin{array}{l}\text { ACAUUCA } \\
\text { GAGUCAA } \\
\text { UCAUCCA }\end{array}$ & $\begin{array}{l}\text { GAUGAUU } \\
\text { GACUCUG } \\
\text { AAUGUCG }\end{array}$ & 18.1 & 13.6 & 37 & -34.40 \\
\hline & NM_004448.3 & $3136-3158$ & $\begin{array}{l}\text { ACAUUCA } \\
\text { GAGUCAA } \\
\text { UCAUCCA }\end{array}$ & $\begin{array}{l}\text { GAUGAUU } \\
\text { GACUCUG } \\
\text { AAUGUCG }\end{array}$ & 18.1 & 13.6 & 37 & -34.40 \\
\hline & NM_001289936.1 & $3412-3434$ & $\begin{array}{l}\text { ACAUUCA } \\
\text { GAGUCAA } \\
\text { UCAUCCA }\end{array}$ & $\begin{array}{l}\text { GAUGAUU } \\
\text { GACUCUG } \\
\text { AAUGUCG }\end{array}$ & 18.1 & 13.6 & 37 & -34.40 \\
\hline & NM_001005862.2 & $3361-3383$ & $\begin{array}{l}\text { ACAUUCA } \\
\text { GAGUCAA } \\
\text { UCAUCCA }\end{array}$ & $\begin{array}{l}\text { GAUGAUU } \\
\text { GACUCUG } \\
\text { AAUGUCG }\end{array}$ & 18.1 & 13.6 & 37 & -34.40 \\
\hline Her3 & NM_001982.3 & $5237-5259$ & $\begin{array}{l}\text { CUCGGAA } \\
\text { UUUCUCU } \\
\text { ACUUUAU }\end{array}$ & $\begin{array}{l}\text { GCCUUAA } \\
\text { AGAGAUG } \\
\text { AAAUAAA }\end{array}$ & 7.2 & 11.0 & 32 & -8.40 \\
\hline \multirow{3}{*}{ Her4 } & XM_005246376.1 & 3373-3395 & $\begin{array}{l}\text { AAUAAAU } \\
\text { CAGGGAU } \\
\text { UUCUCGC }\end{array}$ & $\begin{array}{l}\text { GAGAAAU } \\
\text { CCCUGAU } \\
\text { UUAUUAG }\end{array}$ & 1.0 & 14.0 & 32 & -5.10 \\
\hline & XM_005246375.1 & $3427-3449$ & $\begin{array}{l}\text { GACGUGA } \\
\text { UAACUGC } \\
\text { AAAUGUA }\end{array}$ & $\begin{array}{l}\text { GCACUAU } \\
\text { UGACGUU } \\
\text { UACAUGG }\end{array}$ & 14.7 & 11.6 & 37 & -6.30 \\
\hline & NM_001042599.1 & $3231-3253$ & $\begin{array}{l}\text { CUCCUUU } \\
\text { CUACGGU } \\
\text { UAAUUUA }\end{array}$ & $\begin{array}{l}\text { GGAAAGA } \\
\text { UGCCAAU } \\
\text { UAAAUGG }\end{array}$ & -9.7 & 14.8 & 32 & -4.30 \\
\hline
\end{tabular}




\section{RESULT AND DISCUSSION}

The SNP identified in HER1 receptor is a missense mutation that causes an amino acid substitution from Glycine to serine resulting in abnormal function of the protein. In HER 2 family at five different positions a similar Missense SNP was observed resulting in an amino acid substitution from proline to Alanine leading to structural and functional alteration of the protein. In HER3 receptor the single SNP is a missense mutation that leads to substitution of Serine to Arginine. In HER4 family at three different positions the same Missense SNP was identified that leads to substitution of proline to serine. Since all these SNPs occurring at the nucleotide level are altering the protein sequence structure and function, in the present study SiRNAs were designed for all the mRNA sequences including the SNP changes.

The mRNA sequences with SNPs at the positions listed in Table 1 were submitted to the siRNA Direct 2.0. The results obtained were a set of possible siRNA sequences with 21 nucleotides and the positions where they are targeted. The best possible siRNA sequences were chosen after performing validation. The BLAST search performed confirms that off-targeting is minimized. The GC content of the siRNA sequences is in an optimum range (as listed in Table 3). The RNA-RNA interactions energy is given in Table 3 which shows the list of receptors, their reference mRNA sequences, position on the mRNA sequence where the siRNA molecule is targeted, the guide and passenger sequences, GC content and free binding energy.

\section{CONCLUSION}

siRNA design enables gene silencing for many of the target genes. In the present study, the target genes that were selected belong to HER family. This family of genes includes HER receptors that have a significant role in cancer. Our computational studies resulted in designing of siRNA molecules against HER receptors. These siRNA molecules may prove to be anticancer agents and hence can be used by pharmaceutical industry for the development of new class of anticancer agents that are effective at genomic level.

\section{ACKNOWLEDGEMENTS}

Firstly, I would like to express my sincere thanks to the management of Sreenidhi Institute of science and Technology (SNIST) for providing facilities in Bioinformatics laboratory. My sincere thanks goes to Dr. V. Sesha Srinivas, Professor and Head, Department of Biotechnology, SNIST for his insightful comments and encouragement during our research.

\section{CONFLICT OF INTEREST}

All authors have equally Participated in the acquisition, design, and/or interpretation of the results and in drafting and/or revising the manuscript. All the authors had full access to all of the data in this study and I take complete responsibility for the integrity of the data and the accuracy of the data analysis.

\section{ABBREVIATION}

$\begin{array}{ll}\text { siRNA: } & \begin{array}{l}\text { Small interfering Ribo nucleic } \\ \text { acid }\end{array} \\ \text { SNP: } & \begin{array}{l}\text { Single nucleotide } \\ \text { polymorphism }\end{array} \\ & \begin{array}{l}\text { Human Epidermal growth } \\ \text { factor receptor }\end{array} \\ \text { HER: } & \text { RNA induced silencing } \\ & \text { complex } \\ \text { RISC: } & \begin{array}{l}\text { Epidermal growth factor } \\ \text { receptor }\end{array} \\ \text { EGFR: } & \text { Mitogen activated protein } \\ \text { kinases } & \text { Phosphatidylinositol 3-kinase } \\ \text { MAPK pathway: } & \text { Signal transducer and activator } \\ \text { of transcription 3 } & \text { Focal Adhesion Kinase } \\ \text { PI3K pathway: } & \text { pathway } \\ \text { STAT3 pathway: } & \text { Epidermal growth factor }\end{array}$

\section{Highlights of Paper}

- The present work is about siRNA design for the most commonly occurring SNPs of HER family of receptors that has known to cause various types of cancer.

- These siRNAs designed by the software are targeted against the mRNA in which SNP has occurred.

- The siRNA cleaves the mRNA leading to the efficient inhibition of gene expression.

- The best siRNA is selected from a set siRNA designs generated by the software considering the various parameters.

- Further studies can be performed on these siRNAs so that it could be a potential solution for curing cancer. 
- Dr. Ravindra Babu Potti: Has 18 years of experience in Teaching and Research. He was awarded Ph.D from Acharya Nagarjuna University, Guntur, Andhra Pradesh. His area of expertise is in Industrial Biotechnology and Bioinformatics. He is working as Associate Professor in Department of Biotechnology at Sreenidhi Institute of Science and Technology, Hyderabad. He has over 15 peer reviewed Journal publications. He was an invited speaker at various national and International conferences. He has organized various refresher courses. Presently, he has six scholars working under his guidance for Doctoral Program.

\section{REFERENCES}

1. Gene Silencing. National Center for Biotechnology Information Retrieved 11 November; 2013.

2. Hannon GJ. RNA interference. Nature 2002; 418(6894): 244-51.

3. Filipowicz W. RNAi: the nuts and bolts of the RISC machine. Cell 2005; 122(1): 17-20.

4. Carthew RW, Sontheimer EJ. Origins and Mechanisms of miRNAs and siRNAs. Cell 2009; 136(4): 642-55.

5. Ménard S, Tagliabue E, Campiglio M, Pupa SM. Role of HER2 gene overexpression in breast carcinoma. J Cell Physiol. 2000; 281(2): 150-62.

6. Sorkin A, Goh LK. Endocytosis and intracellular trafficking of ErbBs. Exp Cell Res. 2008; 315(4): 3093-106.

7. Ménard S, Tagliabue E, Campiglio M, Pupa SM. Role of HER2 gene overexpression in breast carcinoma. J Cell Physiol. 2000; 281(1): 150-62.

8. Slamon DJ, Godolphin W, Jones LA, et al. Studies of the HER2/ neu protooncogene in human breast and ovarian cancer. Science 1989; 244(4905): 707-12.

9. Prenzel N, Fischer OM, Streit S, et al. The epidermal growth factor receptor family as a central element for cellular signal transduction and diversification. Endocr Relat. Cancer 2001; 8(1): 1131.

10. Hynes NE, Stern DF. The biology of erbB2/ neu/HER2 and its role in cancer. Biochim Biophys Acta. 1994; 1198(2): 165-84.

11. Linggi $B$, Carpenter $G$. ErbB receptors: new insights on mechanisms and biology. Trends Cell Biol. 2006; 16(12): 649-56.

12. Herbst RS, Bunn PA. Targeting the epidermal growth factor receptor in non-small cell lung cancer. Clin Cancer Res. 2003; 9 (16 Pt 1): 5813-24.

13. Ettinger DS. Clinical implications of EGFR expression in the development and progression of solid tumors: focus on non-small cell lung cancer. Oncologist 2006; 11(4): 358-73.

14. Prenzel N, Fischer OM, Streit S, et al. The epidermal growth factor receptor family as a central element for cellular signal transduction and diversification. Endocr Relat. Cancer 2001; 8(1):11-31.

15. Fujino S, Enokibori T, Tezuka N, et al. A comparison of epidermal growth factor receptor levels and other prognostic parameters in non-small cell lung cancer. Eur J. Cancer 1996; 32A(12): 2070-4.

16. Rusch V, Baselga J, Cordon-Cardo C, et al. Differential expression of the epidermal growth factor receptor and its ligands in primary non-small cell lung cancers and adjacent benign lung Cancer. Cancer Res. 1993; 53(10): 2379-85.

17. Mitri Z, Constantine T, O'Regan R. The HER2 Receptor in Breast Cancer: Pathophysiology, Clinical Use, and New Advances in Therapy. Chemother Res Pract. 2012; 2012(743193).

18. Sliwkowski MX, In: Harris JR, Lippman ME, Morrow M, Osborne CK, eds PA: Lippincott Williams and Wilkins. Diseases of the Breast. $3^{\text {rd }}$ ed. Philadelphia; 2004. 415-26.

19. Ménard S, Tagliabue E, Campiglio M, Pupa SM. Role of HER2 gene overexpression in breast carcinoma. J Cell Physiol. 2000; 182(2): 150-62.

20. Campiglio M, Ali S, Knyazev PG, Ullrich A. Characteristics of EGFR family-mediated HRG signals in human ovarian cancer. J
Cell Biochem. 1999; 73(4): 522-32.

21. Prigent SA, Lemoine NR, Hughes CM, Plowman GD, Selden C, Gullick WJ. Expression of the c-erbB-3 protein in normal human adult and fetal tissues. Oncogene 1992; 7(7): 1273-8.

22. Sergina NV, Rausch M, Wang D, et al. Escape from HER-family tyrosine kinase inhibitor therapy by the kinase-inactive HER3. Nature 2007; 445(7126): 437-41.

23. Hsieh AC, Moasser MM. Targeting HER proteins in cancer therapy and the role of the non-target HER3. Br J. Cancer 2007; 97(4): 453-7.

24. Alimandi M, Romano $A$, Curia MC, et al. Cooperative signaling of ErbB3 and ErbB2 in neoplastic transformation and human mammary carcinomas Oncogene 1995; 10(9): 1813-21.

25. Prigent SA, Gullick WJ. Identification of c-erbB-3 binding sites for phosphatidylinositol 3'-kinase and SHC using an EGF receptor/cerbB-3 chimera. EMBO J. 1994; 13(12): 2831-41.

26. Soltoff SP, Carraway III KL, Prigent SA, Gullick WG, Cantley LC. ErbB3 is involved in activation of phosphatidylinositol 3-kinase by epidermal growth factor. Mol Cell Biol. 1994; 14(6): 3550-8.

27. Tzahar $\mathrm{E}$, Waterman $\mathrm{H}$, Chen $\mathrm{X}$, et al. A hierarchical network of interreceptor interactions determines signal transduction by $\mathrm{Neu}$ differentiation factor/neuregulin and epidermal growth factor. Mol Cell Biol. 1996; 16(10): 5276-87.

28. Ejskjaer K, Sørensen BS, Poulsen SS, et al. Expression of the epidermal growth factor system in endometrioid endometrial cancer. Gynecol Oncol. 2007; 104(1): 158-67.

29. Olayioye MA, Neve RM, Lane HA, Hynes NE. The ErbB signaling network: receptor heterodimerization in development and cancer EMBO J. 2000; 19(3): 3159-67.

30. Campiglio M, Ali S, Knyazev PG, Ullrich A. Characteristics of EGFR family-mediated HRG signals in human ovarian cancer. J Cell Biochem. 1999; 73(4): 522-32.

31. dbSNP http://www.ncbi.nlm.nih.gov/SNP/snp_summary.cgi

32. Yoshimura J, Morishita S, Ui-Tei K. siDirect 2.0: updated software for designing functional siRNA with reduced seed-dependent offtarget effect. BMC Bioinformatics 2009; 10(1): 392.

33. Gupta SK, et al. A Novel Algorithm to Design an Efficient siRNA by Combining the Pre Proposed Rules of siRNA Designing. J Compur Scie and Syst Biol. 2010; 3(1): 005-9.

34. Ui-Tei K, Naito $Y$, Takahashi F, Haraguchi T, Ohki-Hamazaki $H$, Juni A, et al. Guidelines for the selection of highly effective siRNA sequences for mammalian and chick RNA interference. Nucleic Acids Res. 2004; 32(3): 936-48.

35. Ui-Tei K, Naito Y, Nishi K, Juni A, Saigo K. Thermodynamic stability and Watson-Crick base pairing in the seed duplex are major determinants of the efficiency of the siRNA-based off-target effect. Nucleic Acids Res. 2008; 36(22): 7100-9.

36. Yamada T, Morishita S. Accelerated off-target search algorithm for siRNA. Bioinformatics 2005; 21(8): 1316-24.

37. Altschul SF, et al. Basic local alignment search tool. J Mol Biol. 1990; 215(3): 403.

38. Gruber AR, et al. The vienna RNA websuite. Nucleic Acids Res. 2008; 36(suppl 2): W70-4. 